\title{
Geo-Electric Assessment of Kali Failed Dam Project Aliero, North Western Nigeria
}

\author{
U. Z. Magawata1 ${ }^{*}$, Ibrahim Mohammed ${ }^{2}$, B. A. Ojulariं ${ }^{3}$, A. I. Augie ${ }^{4}$, Salisu Musa ${ }^{5}$ \\ ${ }^{1}$ Department of Physics, Kebbi State University of Science and Technology, Aliero, Nigeria \\ ${ }^{2}$ Department of Preliminary Studies, Waziri Umaru Federal Polytechnic Birnin Kebbi, Birnin Kebbi, Nigeria \\ ${ }^{3}$ Department of Chemical, Geological and Physical Science, Kwara State University, Malete, Nigeria \\ ${ }^{4}$ Department of Geophysics, Federal University Birnin Kebbi, Birnin Kebbi, Nigeria \\ ${ }^{5}$ Department of Physics, Bayero University Kano, Kano, Nigeria \\ Email: *uzayyanu@yahoo.com
}

How to cite this paper: Magawata, U.Z., Mohammed, I., Ojulari, B.A., Augie, A.I. and Musa, S. (2020) Geo-Electric Assessment of Kali Failed Dam Project Aliero, North Western Nigeria. International Journal of Geosciences, 11, 1-13. https://doi.org/10.4236/ijg.2020.111001

Received: October 29, 2019

Accepted: January 28, 2020

Published: January 31, 2020

Copyright $\odot 2020$ by author(s) and Scientific Research Publishing Inc. This work is licensed under the Creative Commons Attribution International License (CC BY 4.0).

http://creativecommons.org/licenses/by/4.0/

cc) (i) Open Access

\begin{abstract}
An integrated geophysical investigation using very low frequency electromagnetic (VLF-EM) and electrical resistivity methods using (VES) technique has been carried out for investigation of possible causes of dam failure in Kali, Aliero Northwestern Nigeria. A total of Three 3 (VLF-EM) traverses and Ten 10 vertical electrical soundings (VES) techniques have been carried out to identify the fracture zones, seepage and possible threat that lead to the collapse of the dam. The interpretation of VLF-EM data is carried out qualitatively using Fraser and Karous-Hjelt filters and the interpretation of sounding data is done using IPI2 win software. VLF-EM data signifies the exact fracture zones founded on higher values of relative current density that coincide to the subsurface fracture. The survey was conducted on an interval of $10 \mathrm{~m}$ interval along traverses at South-North direction ranging from $620-640 \mathrm{~m}$ in length. The plot of filtered real and filtered imaginary identified noticeable fracture zone close to the surface which was later further delineated by (VES) technique. VES soundings were carried out at locations of prominent VLF anomalies presumably typical of basement fracture using $A B / 2$ of $80 \mathrm{~m}$. Results interpreted show layers thickness and their corresponding resistivity, top soil ( $0.5 \mathrm{~m}$ to $3.45 \mathrm{~m}, 51.9 \Omega \mathrm{m}$ to $318 \Omega \mathrm{m}$ ), underlain by clay to confined clay ( $4.56 \mathrm{~m}$ to $54 \mathrm{~m}, 7.88 \Omega \mathrm{m}$ to $60.2 \Omega \mathrm{m}$ ) which is underlain by fractured/fresh basement ( $5.76 \mathrm{~m}$ to $73.9 \mathrm{~m}, 40.3 \Omega \mathrm{m}$ to $197 \Omega \mathrm{m}$ ). The overburden materials underlain are far away to subsurface (bed rock) in most of the area to support the dam. The clay materials which could serve as conduit, exist within the shallow overburden which was not excavated during the construction. Therefore it was concluded that the dam cannot retain its strength to oppose the dam against collapse.
\end{abstract}




\section{Keywords}

Failure, Appropriate, Presumably, Fractures, Anomaly, Prospective

\section{Introduction}

Kali dam in Aliero, Kebbi State Northwestern Nigeria, is the dam constructed for domestic water usage and irrigation purposes. During the dry season, the depth to reservoirs water level reduces to $<2.5 \mathrm{~m}$ while in the wet season, it is always filled and overflows the dam axis. The reduction in water level necessitated the investigation of the possible cause, which could be the result of several environmental or natural factors such as seepage, substandard dam construction, dam gate damage and many more [1]. Seepage through a dam is a slow discharge or escape of liquid that is supposed to be retained in the reservoir, through conduits (fracture/fault lines) to the flank of the dam. It reduces the expected quantity of water, weaken dam construction and damage dam gates. Certain soil can swell if they get saturated with the seeping water and when there is loss of water in them, they shrink drastically. These expansions and shrinkages of soils can result in cracks and collapse of the dam. Seepage is one of the major reasons for embankment dam failures and may constitute a significant potential social dislocation (displacement of people, loss of valuable life and properties) if not examined.

Geophysical methods together with or beside other geotechnical approaches are routinely used for foundation investigation as studied by [2] [3] [4]. Geophysical methods such as the Electrical Resistivity (ER), Seismic refraction, Electromagnetic (EM), Magnetic and Ground Penetrating Rader are used singly or in combinations for engineering site investigation as studied by [5] [6] [7]. The applications of such geophysical investigation are in the determination of layer thickness, depth to bedrock, structural mapping and evaluation of subsoil competence. In other words, an adequate assessment of geologic and geotechnical conditions of the proposed site is imperative for a safe dam design and construction [8]. Most of the dam failure can be linked to geologic and geotechnical problems. The geologic and geotechnical problems range from foundation defects caused by inadequate investigation to internal erosion through the embankment to siting dam on regional geologic structures such as fault. Each dam site may have its own unique set of geologic and geotechnical challenges since the design requirements are different for dams of different size, purpose and hazard potential classification. Geotechnical geophysics is an important exploration tool for dam site investigation. It is the application of geophysics to geotechnical engineering problems; such investigations normally extend to a total depth of less than several hundred feet but can be extended to thousands of feet in some instances. It is routinely used for many types of dam site and highway engineering investigations including site characterization and estimation of en- 
gineering properties of earth materials [9]. Very Low Frequency electromagnetic (VLF-EM) method, among the geophysical methods literarily serves as reconnaissance survey tool for subsurface delineation while magnetic survey has been extensively used in basement mapping and to delineate subsurface linear geologic structures which may be related to groundwater accumulation by locating rocks or minerals having unusual magnetic properties which reveals themselves as anomalies in the intensity of the earth's magnetic field [10] and electrical Resistivity (ER) alone of the most sensitive geophysical methods for the changes in soil moisture and a very effective tool to determine depth to water saturated zone and groundwater flow pattern. In the case of water seepage through a dam, it can be detected as resistivity low using electrical resistivity methods [11] [12].

An integrated geophysical survey (using vertical electrical sounding and very low frequency (VLF EM) method was done in order to: 1) determine the optimal depth to bedrock. 2) To use raw VES data to Prepare apparent resistivity pseudo section. 3) Map the subsurface conductive zones and geologic structures using the VLF-EM method. 4) Delineate zones of weakness and thereby evaluate the stability conditions, causes of the failure of the dam structure in question. The principal goal of this work is to provide information on the subsurface geology of the area of study using complimentary results from the two methods.

\section{Description of Study Area}

The study was conducted within the Aliero town, Kebbi State Northwestern Nigeria, located between latitude $12^{\circ} 16^{\prime} 634^{\prime \prime}$ and longitude $4^{\circ} 27^{\prime} 448^{\prime \prime}$, conformably in a Gwandu Formation, the formation crops out over 8500 square miles in the western third of the Sokoto Basin. The sediments of terrestrial origin are made up of interbedded semi consolidated sand and clay. The clay beds of the Gwandu are commonly thick and massive and white, red, or gray brown to black. The sand beds are fine to very coarse, predominantly quartz containing some limonite nodules, cemented in places by limonite. Lignite is common in some beds of black peaty clay and whitish-gray sand. Characteristically, sand beds underlie the low plains, and resistant clay beds form the tabular-shaped hills capped with residual ironstone. The Gwandu Formation unconformably overlies the Kalambaina Formation in the northern and central parts of the Sokoto Basin. Southward, however, the Gwandu overlaps the Kalambaina and rests directly on the Rima and Illo Groups in the southern part of the basin. The erosional outliers of the Gwandu on these older formations indicate its once greater areal extent. From a featheredge at its eastern limit in the central part of the Sokoto Basin, the formation thickens to the northwest and downdip to about 1000 feet near the Niger frontier. The regional dip of the base of the Gwandu is 17 feet per mile toward the northwest. Birnin Kebbi is dominated by two formations; Precambrian Basement Complex in the southern and south east young sedimentary rocks in the north. The Basement Complex region is composed of very old volcanic and metamorphic rocks such as granites schist's, gneisses, quaetzites and migmatites. In addition there are met sediments such as phyllites and met Con- 
glomerates [13]. The sedimentary region consists of the Gwandu, Illo and Rima groups whose ages range from the cretaceous to the Ecocene. The Gwandu group consists of massive clay grits inter bedded with sand stone while the Illo and Rima groups consist of pebby grits, sand stone and clays mudstone and siltstone respectively.

\section{Material and Methods}

A careful study of existing geology of the area indicates that the study area is underlain by the Gwandu Formation. Geophysical survey was carried out on the site. Vertical Electrical resistivity soundings were undertaken using ABEM SAS 300 Terrameter by means of the Schlumberger system of electrodes arrangement. The points have a maximum electrodes separation of $A B / 2$. This type of electrode configuration has been used World Wide with satisfactory results. The method of electrical sounding furnishes detail information on the vertical succession of different conducting zones and their individual thickness and true resistivity. For this reason, the method is particularly valuable for nearly horizontal stratified ground. Ten (10) VES stations were conducted along a profile that runs E-W with 600 meters distance along the failed structure. This orientation was chosen in conformity with the W-E direction of the failed segment.

Three (3) very low frequency (VLF EM) were established, the length of the VLF traverse were determined by the length of the embankment which are about 620 meter for each of the three (3) traverses with station interval of 10 Metre. The method is based on measurement of the secondary magnetic field induced in local conductors by primary electromagnetic fields generated by the powerful military radio transmitter in the very low-frequency range $(15-30 \mathrm{KHz})$. The entire ABEM WADI system is portable equipment mounted on a belt worn by the user. The hand-held controller unit contains a microcomputer, keyboard and screen where measurements are displayed and stored. The AbemWadi measures the field strength and the phase displacement around the fracture zone and presents it as raw and filtered data. The EM data was interpreted and inverted into a 2-D section using the Karous-Hjelt filterin [14]. The anomaly inflections appear as peak positive anomalies and false VLF anomaly inflections as negative anomalies on the profiles. The depth of penetration $(d)$ at which the amplitude of the field $A d$ is decreased by a factor $e-1$ compared with its surface amplitude was adopted:

$$
A 0 A d=e-1
$$

In this case

$$
D=503.8(\sigma f)^{1 / 2}
$$

where " $d$ " is metres, the conductivity of the ground $\sigma$ is in $\mathrm{Sm}^{-1}$ and the frequency $\mathrm{f}$ of the field is in $\mathrm{Hz}$. The depth of penetration thus increases as both the frequency of the electromagnetic field and the conductivity of the ground decrease. 
Electrical resistivity can be used, it proved useful in identification of seepage pathways associated with dam foundation materials and internal erosion detection [15]. The electrical resistivity method employ for this study by applying the fundamental principle of OMS law.

$$
V r=\frac{P I}{2 \pi r}
$$

where $V r$ is the electric potential at any point $P$ distance $r$ from a point electrode emitting an electric current $I$ in an infinite homogenous and isotropic medium of Resistivity $\rho$. The resistance data were acquired with the Campus-Omega resistivity meter which contains both the transmitter unit, through which current enters the ground and the receiver unit, through which the resistance is recorded and multiplied by the standard geometric factor $(G)$ of Schlumberger array technique to get the apparent resistivity of each points.

$$
\begin{gathered}
G=\pi \frac{\left[(A B)^{2}-(M N)^{2}\right]}{2\left(\frac{(M N)^{2}}{2}\right)} \\
\rho a=R G
\end{gathered}
$$

The $12 \mathrm{~V}$ direct current (DC) served as current source to the Terrameter, and the current was passed into the subsurface through the two current electrodes " $A B$ " while the two potential electrodes " $M N$ " were linearly arranged along the survey line to determine the ground potential difference (Figure 1).

\section{Result and Discussion}

The contoured apparent resistivity pseudo section was produced from plots of VES points against electrode spacing. Interpretation of the curves generated was done qualitatively through visual inspection and quantitatively using IP2W in computer software as well as the pseudo section was generated using same software. The field curves show 3 three to 4 four layers case. Most of the curves indicate multiple increases and decreases of resistivity with depth in some locations. Appendix I is the field curves along Aliero fail dam embankment. The resistivity pseudo section map covers a total horizontal distance of about $600 \mathrm{~m}$. The area is underlain by upper sand and clay (fine to coarse sand) or top soil, confining clay and artisan aquifer. The results of the VLF-EM plots along each traverse are presented in figures and showed varied anomalies with narrow, sharp or broad peaks with varying width extent using karos Hijelt software. The curves with maximum positive peak of filtered real with corresponding low filtered imaginary curves were delineated and identified as area with high conductivity which is the characteristic of water-filled fractures or faults and therefore can serve as a good auriferous zones. Geological interfaces were delineated using characteristic features of coincident inflection on real component anomaly curves [16]. These interfaces are near-surface/subsurface fracture usually identified as linear features of water saturated, they normally constitute good aquifers 


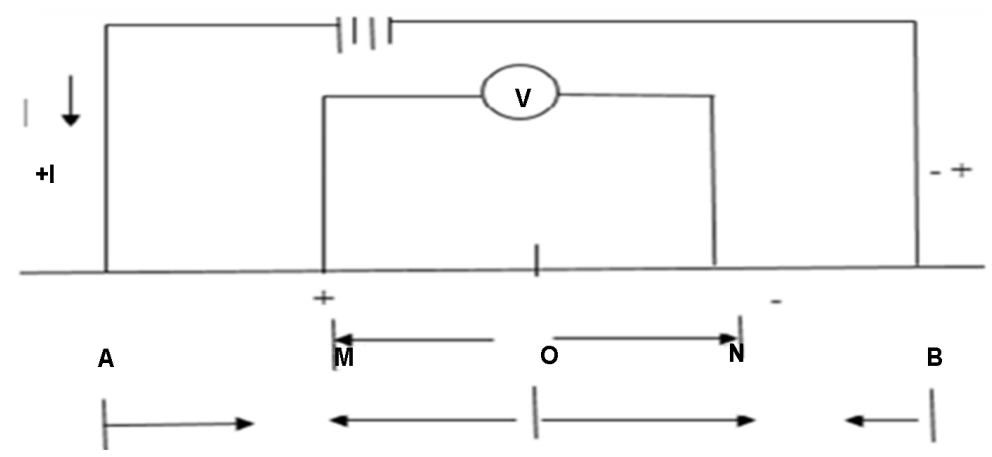

Figure 1. Schlumberger configuration array.

that cause dam sea page [16], indicated that the strength of the in-phase component expressed in percentage is directly proportional to the yield of the water, further the strength of the VLF anomaly depend on the contrast between the electrical conductivity in water-bearing fracture zone that gives rise to the anomaly in an electrical conductivity of the surrounding bedrock.

\subsection{Interpretation of Very Low Frequency (VLF EM) Results}

The Fraser techniques were applied to filter the in-phase/real real data and composite graphs of Fraser filtered responses against distance were obtained on a single Cartesian plain along each transverse using Karos Hijelt Filter software [14], confirmed that the cross over points (i.e. Intersection of in-phase and quadrature plots) indicates fracture or share zones. It is sometimes associated with vertical contacts between intrusive materials and the country rocks. It is further reported that the cross-over between the real and imaginary components of the VLF-EM field data indicate conductive zones in the subsurface. These conductive zones are probably fractures in the basement rock, which are possible zones of weakness such as fracture in the subsurface. The cross-over zones were transformed into peaks by Fraser filter, which further confirm the conductive zones. High conductivity of zones, which are possible zones of weakness are depicted by peak red color. Each traverse is presented sequentially.

\subsubsection{Transverse 1}

Transverse 1 (620 $\mathrm{m}$ long) is in the vicinity of the main reservoir of kali, Aliero dam Prominent cross-over point that depict the exact location of the subsurface fractures appear within $50 \mathrm{~m}, 200 \mathrm{~m}$ and $400 \mathrm{~m}$ from the starting point of the profile (Figure 2(a)). The fracture zone appears as a positive peak, indicating a conductive characteristic, compared with the surrounding rocks. The inferred pseudo section (Figure 2(b)) shows that the fracture content is resistive with a response signal of around $-50 \%$ and extends beyond a depth of 60 $\mathrm{m}$, the model further shows that the area along this profile is generally underlain by a resistive rock, the most prominent identified homogeneously at 220 $\mathrm{m}$. Thus, the pore there could indicate presence resistive bodies such as clay, sand or empty space. 


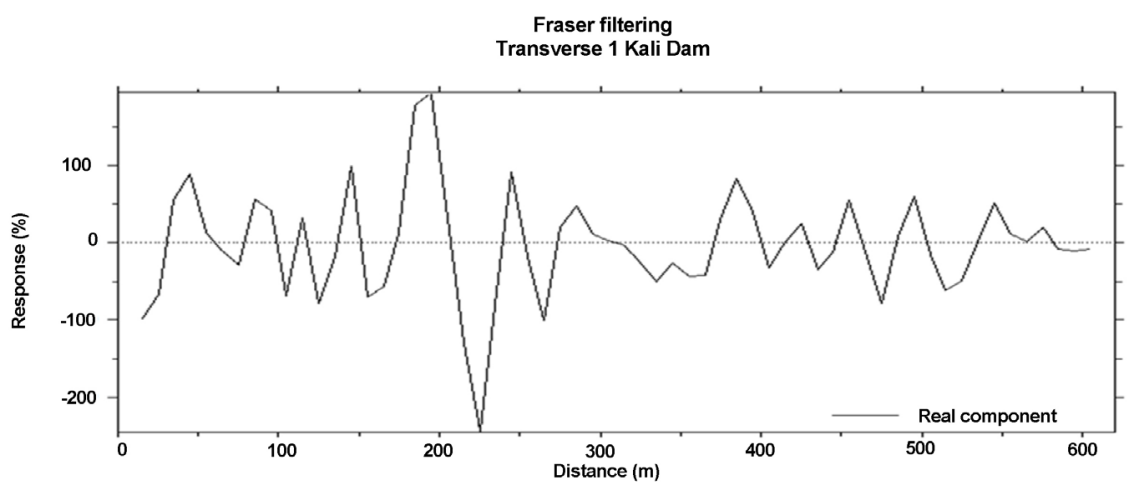

(a)

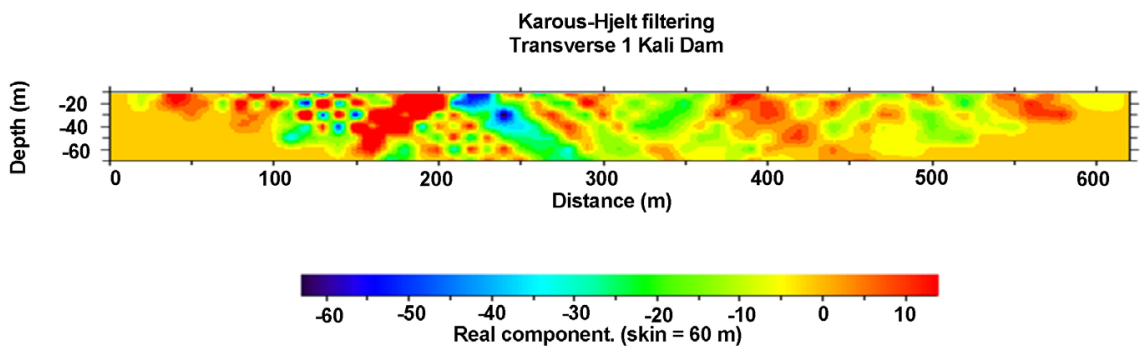

(b)

Figure 2. Plot of VLF results along the Traverse 1, (a) unfiltered Real component of VLF-EM data, Fraser filtered real (in-phase) data against distance, (b) Karous and Hjelt pseudo-section of in-phase data (apparent current density pseudo-section) against distance.

\subsubsection{Transverse 2}

Transverse 2 is parallel to traverse 1 in the same location at the dam embankment with length of $640 \mathrm{~m}$. A prominent fracture appears at subsurface at distance $40-80 \mathrm{~m}, 120-280 \mathrm{~m}$ and $380-500 \mathrm{~m}$ (Figure 3(a)). The minimum signal response is $+50 \%$ upward and it extends beyond $40 \mathrm{~m}$ depth at some points. The fracture depicts a high conductive zone (Figure $3(\mathrm{~b})$ ). There is an evidence of low consolidation at the beginning of this profile but the consolidation increases towards its end with exception of some minor location i.e. $100 \mathrm{~m}$ and 520 $\mathrm{m}$ that indicate resistive zone.

\subsubsection{Traverse 3}

transverse 3 is at the dam canal with a total length of $620 \mathrm{~m}$. Highly conductive fracture zones appear at a distance of $100-190 \mathrm{~m}$ and $400-600 \mathrm{~m}$ (Figure 4(a)) with a common signal response of $+100 \%$ and above. The pore could be considered to contain conductive material such as water. At $230-250 \mathrm{~m}$ and $350 \mathrm{~m}$ on the profile, fractures whose content is less conductive appear. The fracture depths start at $20 \mathrm{~m}$ and extend as far as $50 \mathrm{~m}$ in most cases. The fracture system here could be inimical to the stability of the dam in question.

\subsection{Interpretation of VES Results}

The typical sounding curves obtained from the computer iteration of resistivity data are presented in Figure A1 and Figure A3 are shown in Appendix I. 


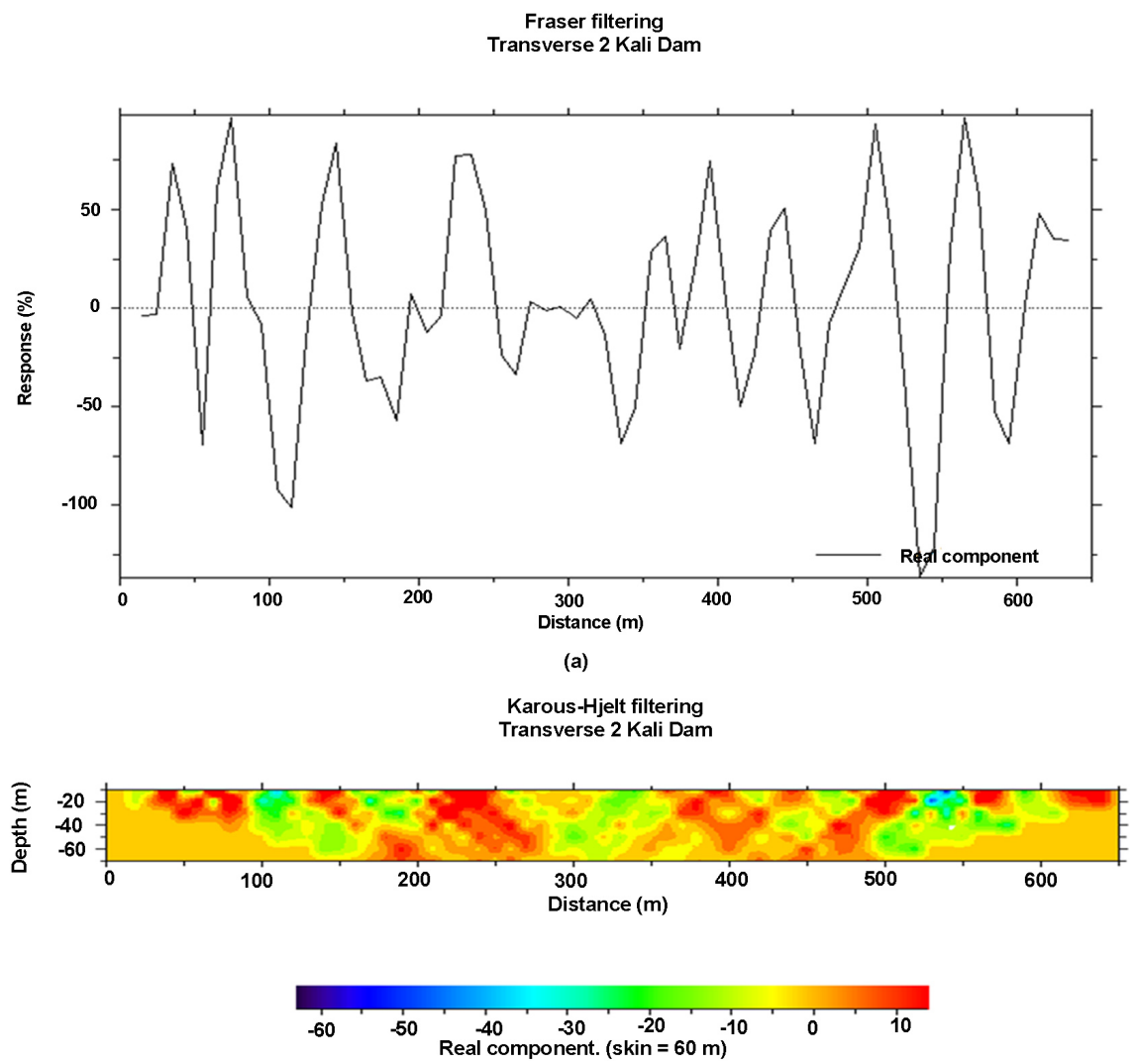

(b)

Figure 3. Plot of VLF results along the Traverse 2, (a) unfiltered Real component of VLF-EM data, Fraser filtered real (in-phase) data against distance, (b) Karous and Hjelt pseudo-section of in-phase data (apparent current density pseudo-section) against distance.

From the resistivity curves the geoelectric layers varies from 3 - 4 in all the traverses. The geoelectric layers delineated correspond to the upper sand and clay or top soil, confining clay and artisan aquifer. This is summarized in Table 1 . The resistivity and thickness of the top soil (upper sand and clay) varies from $51.9 \Omega \mathrm{m}-318 \Omega \mathrm{m}$ and from $0.5 \mathrm{~m}-3.45 \mathrm{~m}$ respectively. The second layer has resistivity and thickness that ranging from $7.88 \Omega \mathrm{m}-60.2 \Omega \mathrm{m}$ and $4.56 \mathrm{~m}-54$ $\mathrm{m}$ which is probably clay to confined clay. Its resistivity varies with degree of saturation. The third layer, artisan aquifer has resistivity range of $40.3 \Omega \mathrm{m}-197$ $\Omega \mathrm{m}$ and thickness of $5.76 \mathrm{~m}-73.9 \mathrm{~m}$ respectively as shown in Table 2 . The Fracture seated in this layer can affect the stability of dam if it extends to the subsurface. In fact the resistivity values captured are almost low in all the 10 VES stations as highlighted by [17], in Table 1 . At a depth of about $4 \mathrm{~m}$ to $35 \mathrm{~m}$, a relatively weak zone with apparent resistivity value ranging as low as $<100 \Omega \mathrm{m}$ is shown in pseudo section (Figure A2) at VES 1 and VES 2 at depth ranging from 5 to $30 \mathrm{~m}$ with low resistivity that are suspected to be clay portion, as compared with remaining 8 VES stations. This weak zone could be as a result of closeness of static water to the subsurface of the area or as the tip of a weathered rock of the sedimentary rock underlying the area. 


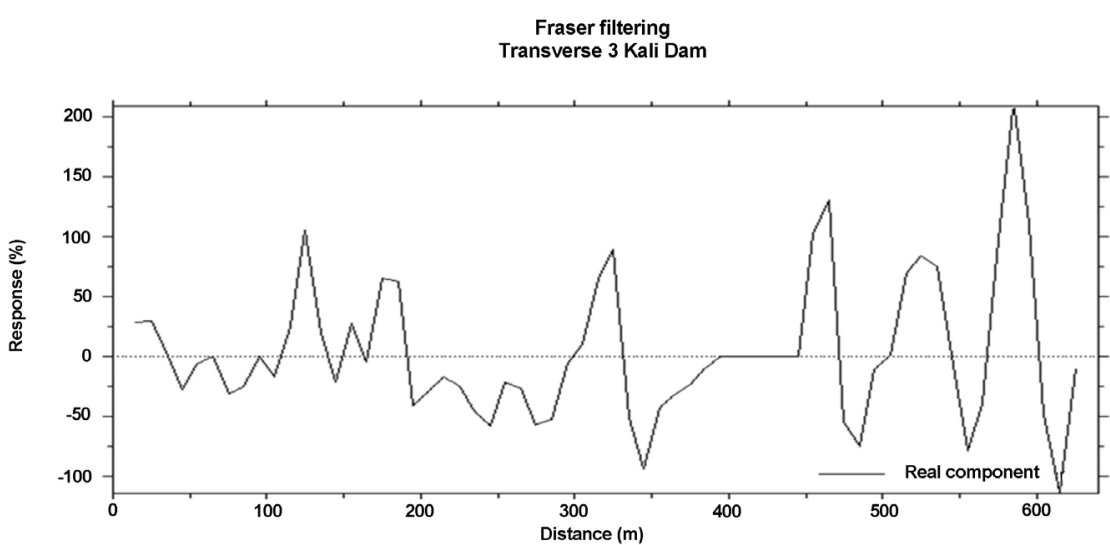

(a)

Karous-Hjelt filtering Transverse 3 Kali Dam
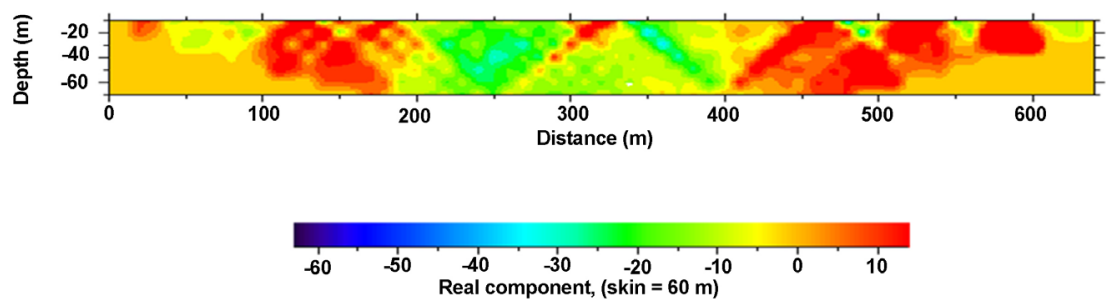

(b)

Figure 4. Plot of VLF results along the Traverse 3, (a) unfiltered Real component of VLF-EM data, Fraser filtered real (in-phase) data against distance, (b) Karous and Hjelt pseudo-section of in-phase data (apparent current density pseudo-section) against distance.

Table 1. Soil competent rating after [17].

\begin{tabular}{ccc}
\hline Apparent resistivity $(\Omega \mathrm{m})$ & Lithology & Competent rating \\
\hline$<100$ & Clay & Incompetent \\
$100-350$ & Sandy Clay & Moderately competent \\
$350-750$ & Clayey Sandy & Competent \\
$>750$ & Sand/Laterite/Bedrock & Highly competent \\
\hline
\end{tabular}

Table 2. Layer resistivity, bed rock and their corresponding thickness.

\begin{tabular}{|c|c|c|c|c|c|c|c|c|c|}
\hline VES & Curve types & $\rho 1(\Omega \mathrm{m})$ & $\rho 2(\Omega \mathrm{m})$ & $\rho 3(\Omega \mathrm{m})$ & $\rho 4(\Omega \mathrm{m})$ & $\mathrm{h} 1(\mathrm{~m})$ & $\mathrm{h} 2(\mathrm{~m})$ & h3 (m) & Bed rock \\
\hline 1 & KHK & 51.9 & 7.88 & 197 & $\infty$ & 3.45 & 4.56 & $\infty$ & 8.01 \\
\hline 2 & KHK & 200 & 44.1 & 48.6 & $\infty$ & 0.5 & 54 & $\infty$ & 54.5 \\
\hline 3 & KHK & 307 & 60.2 & 42.8 & $\infty$ & 0.5 & 10.2 & $\infty$ & 10.7 \\
\hline 4 & KHK & 318 & 59 & 40.3 & $\infty$ & 0.503 & 9.63 & $\infty$ & 10.1 \\
\hline 5 & KHQ & 178 & 48.4 & 56.8 & $\infty$ & 0.82 & 6.44 & $\infty$ & 7.26 \\
\hline 6 & KHK & 179 & 5.86 & 5113 & $\infty$ & 1.26 & 2.07 & $\infty$ & 3.33 \\
\hline 7 & KHK & 164 & 50.2 & 57 & $\infty$ & 0.849 & 14.2 & $\infty$ & 15 \\
\hline 8 & KHK & 153 & 49.8 & 50.7 & 4667 & 0.899 & 5.17 & 73.9 & 80 \\
\hline 9 & KHK & 147 & 49.9 & 9.26 & 4667 & 0.946 & 43.3 & 5.76 & 50 \\
\hline 10 & KHK & 136 & 49.9 & 5.55 & 4667 & 1.04 & 46.8 & 6.37 & 54.2 \\
\hline
\end{tabular}




\section{Conclusion}

Qualitative interpretation of the very low frequency electromagnetic (VLF EM) and Vertical Electrical Sounding (VES) of the Kali failed dam in Aliero Northwestern Nigeria, has delineated a network of lineaments, suspected to be faults, fracture zones and as well as presence of low resistivity below 100 ohms meter which serve as good indication of closeness of static water table that leads to the failure of the dam, the trends generally covered all of area. Interpretation of magnetic profiles confirmed some of these features and suggested that some of the features are seated close subsurface. However the research shows the effectiveness of the combination of VLF-EM and VES survey in accurately delineating an area with fault, fractures and groundwater occurrence, the presence of clay materials close to subsurface become a possible threat to the dam, the observed reduction in reservoir water level could be the result of some environmental factors arise.

\section{Recommendation}

The current research reveals some geophysical features that lead to cause of failure in Aliero dam, to fully identified the causes of this failure geotechnical investigation of the materials used are suggested to conformed the present outcome.

\section{Conflicts of Interest}

The authors declare no conflicts of interest regarding the publication of this paper.

\section{References}

[1] Olasunkanmi, N.K., Aina, A., Olatunji, S. and Bawalla, M. (2018) Seepage Investigation on an Existing Dam Using Integrated Geophysical Methods. Journal of Environment and Earth Science, 8, 6-16. http://www.iiste.org

[2] Ajayi, O., Olorunfemi, M.O., Ojo, J.S., Adegoke, C.W., Chikwendu, K.K., Oladapo, M.I., Idornigie, A.I. and Akinluyi, F. (2005) Integrated Geophysical and Geotechnical Investigation of a Dam Site on River Mayo Ini, Adamawa State, Northern Nigeria. Africa Geoscience Review, 12, 179-188.

[3] Akinrinmade, A.O. (2013) Geophysical and Geotechnical Investigation of River Ero for Dam Site, Ajuba, South-Western Nigeria. M.Sc. Thesis, the Department of Geology, University of Ilorin, Ilorin, 114

[4] Akintorinwa, O.J. and Adeusi, F.A. (2009) Integration of Geophysical and Geotechnical Investigations for a Proposed Lecture Room Complex at the Federal University of Technology, Akure, SW, Nigeria. Ozean Journal of Applied Sciences, 2, 241-254

[5] Olorunfemi, M.O., Idoniege, A.I., Coker, A.T. and Babadiya, G.E. (2004) The Application of the Electrical Resistivity Method in Foundation Failure Investigation, a Case Study of O.A.U Dental Clinic. Global Journal of Geophysical Science, 2, 139-151. https://doi.org/10.4314/gjgs.v2i1.18689

[6] Fatoba, J.O., Alo, J.O. and Fakeye, A.A. (2010) Geoelectric Imaging for Foundation Failure Investigation at Olabisi Onabanjo University (O.O.U) Minicampus, Ago 
Iwoye, Southwestern Nigeria. Journal of Applied Sciences Research, 6, 2192-2198.

[7] Oluwakemi, A.O. and Michael, L.O. (2011) Geoelectric Investigation of Owuruwuru Dam Site, Ikere Ekiti, Southwestern Nigeria. Journal of Geology and Mining Research, 3, 12.

[8] Blyth, F.G.H. and De Freitas, M.H. (1978) A Geology for Engineers. 7th Edition, Edward Arnold Pub., London, 1-325.

[9] Caleb, A.T. and Gabriel, I.O. (2012) Geophysical and Geotechnical Investigation of Cham Failed Dam Project, Ne Nigeria. Research Journal of Recent Sciences, 1, 1-18.

[10] Abderahman, E.M. and Essa, K.S. (2005) Magnetic Interpretation Using a Least-Squares Depth-Shape Curves Method. Geophysics, 70, L23-L30. https://doi.org/10.1190/1.1926575

[11] Aina, A., Olorunfemi, M.O. and Ojo, J.S. (1996) An Integration of Aeromagnetic and Electrical Resistivity Methods in Dam Site Investigation. Geophysics, 61, 349-356. https://doi.org/10.1190/1.1443963

[12] Gamal, Z.A., Ahmed, M.I., Neil, L.A. and Estella, A.A. (2004) Geophysical Investigation of Seepage from an Earth Filled Dam, Washington County MO.

[13] Anderson, H.R. and Ogilbee, W. (1975) Contributions to the Hydrology of Africa and the Mediterranean Region.

[14] Fraser, D.C. (1969) Contouring of VLF-EM Data. Geophysics, 54, 245-253.

[15] Kim, J.H., Yi, M.J., Song, Y., Seol, S.J. and Kim, K.S. (2007) Application of Geophysical Methods to the Safety Analysis of an Earth Dam. Journal of Environmental and Engineering Geophysics, 12, 221-235. https://doi.org/10.2113/JEEG12.2.221

[16] Abem, A.B. (1990) ABEM Instructional Manual: ABEM AB, Bromma, Sweden.

[17] Idornigie, A.I. and Olorunfemi, M.O. (2006) Electrical Resistivity Determination of Subsurface Layers, Subsoil Competence and Soil Corrosivity at an Engineering Site Location in Akungba Akoko, South Western Nigeria. Ife Journal of Science, 8, 22-32. https://doi.org/10.4314/ijs.v8i2.32216 


\section{Appendix I}

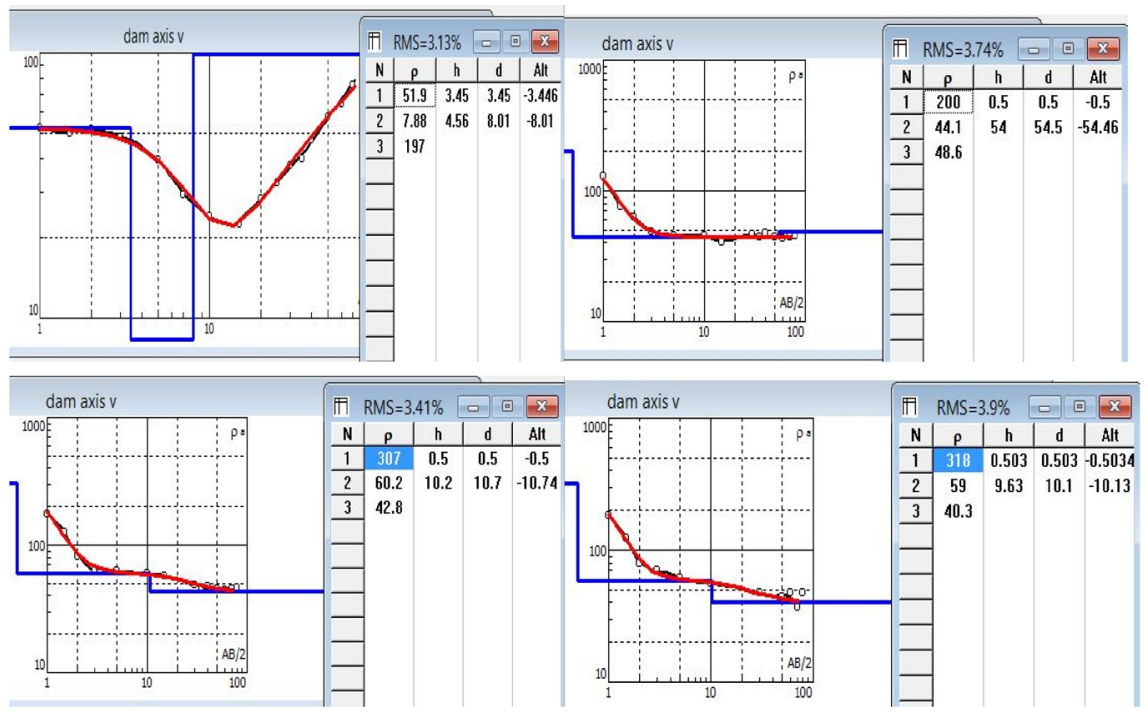

Figure A1. Model result of VES curves at four location VES 1, VES 2, VES 3, and VES 4 respectively.

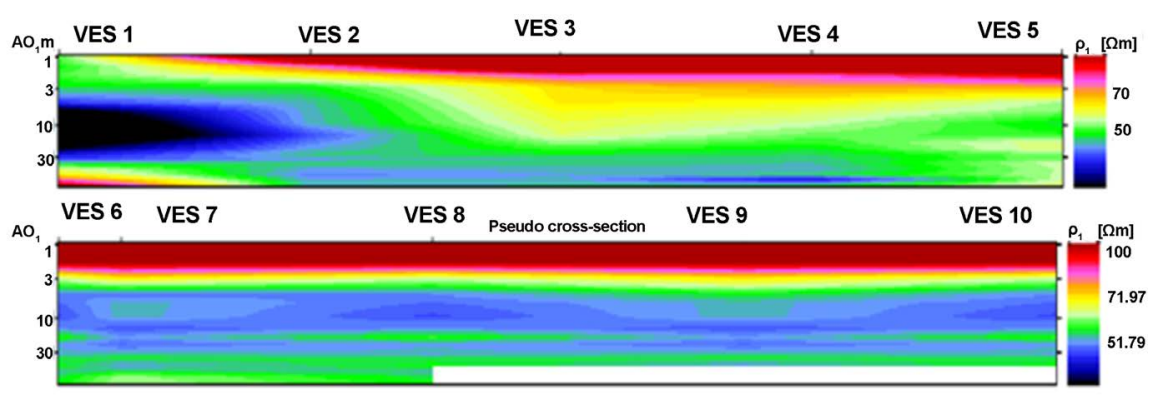

Figure A2. 2D geoelectric pseudo section equivalent of the geologic formation. 

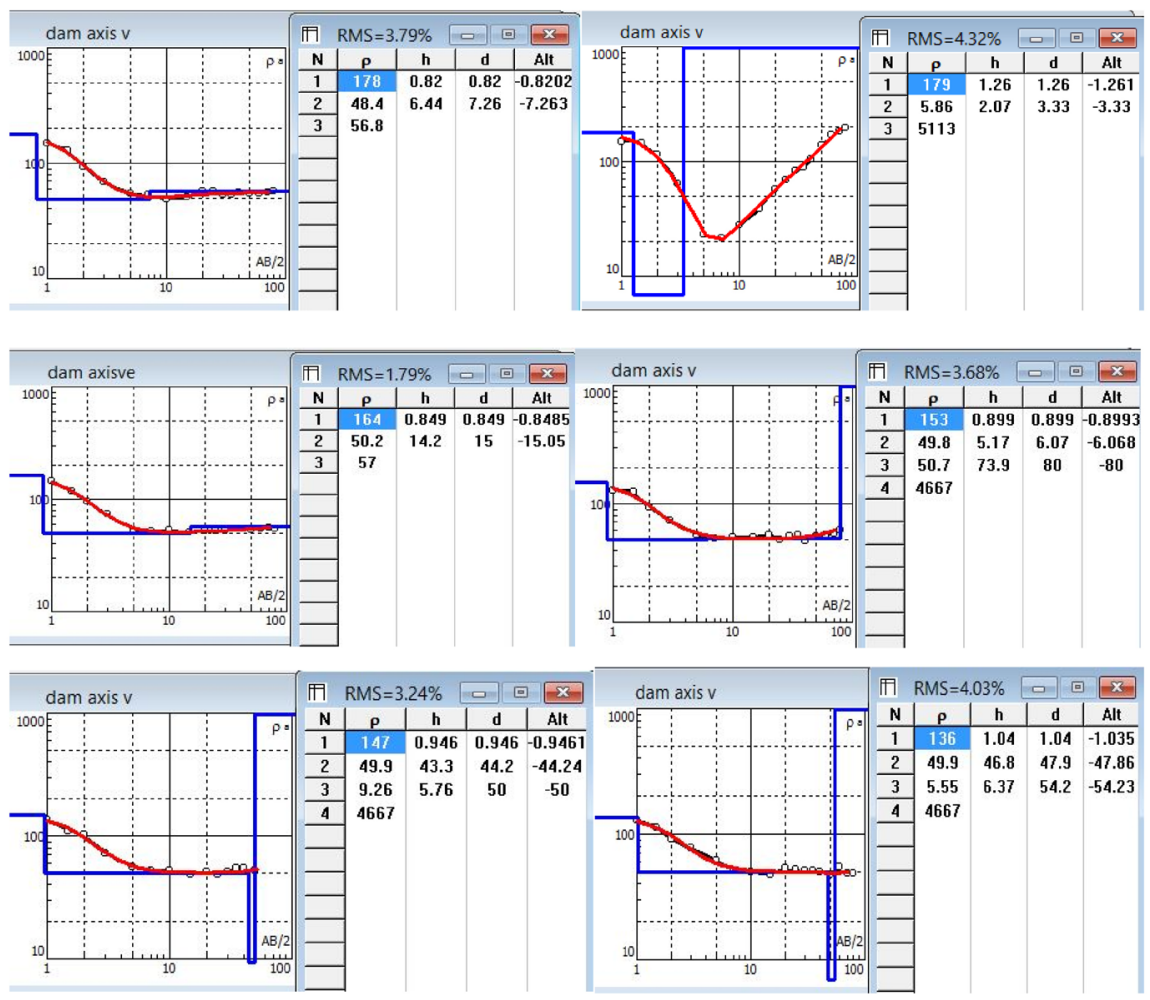

Figure A3. Model result of VES curves at four location VES 5 to VES 10 respectively. 